\title{
Characterization of biodiesel from second generation gamma-irradiated Jatropha curcas
}

\author{
Ibdal Satar, Wan Nor Roslam Wan Isahak, Jumat Salimon* \\ School of Chemical Science \& Food Technology, Faculty of Science and Technology, Universiti Kebangsaan Malaysia, 43600 Bangi, Selangor, Malaysia
}

\section{A R T I C L E I N F O}

\section{Article history:}

Received 20 June 2014

Revised 23 October 2014

Accepted 25 October 2014

Available online xxx

\section{Keyword:}

Jatropha curcas

Biodiesel

Phorbol ester

Alternative fuel

\begin{abstract}
A B S T R A C T
Biodiesel (B2 $\gamma$-300) derived from second-generation gamma-irradiated Jatropha curcas (JCO2 $\gamma-300)$ was analyzed. HPLC and NMR were used to determine the purity of B2 $\gamma-300$, and a value of greater than $99.0 \%$ was verified. Phorbol ester (PE) composition in B2 $\gamma-300$ was analyzed by HPLC but could not be detected. Elemental content of nitrogen $(\mathrm{N})$, carbon $(\mathrm{C})$, hydrogen $(\mathrm{H})$, sulfur $(\mathrm{S})$ and oxygen $(\mathrm{O})$ were analyzed by using NCHS. No sulfur content in B2 $\gamma-300$ could be detected, but N, C, H and O had values of $0.24 \%, 80.54 \%, 6.65 \%$ and $12.57 \%$, respectively. Overall, it was concluded that the physicochemical properties of B2 $\gamma-300$ have potential as source of alternative fuels.
\end{abstract}

(c) 2015 Taiwan Institute of Chemical Engineers. Published by Elsevier B.V. All rights reserved.

\section{Introduction}

Jatropha curcas is a plant that is of interest due to its phorbol ester and oil content. Phorbol ester (PE) compounds are useful in the fields of health, medicine and agriculture [1,2]. J. curcas oil (JCO) is a source material for biodiesel production. Both reasons have driven researchers to produce a new generation of J. curcas (JC2 $\gamma-300)$ using gamma irradiation by a dose of $300 \mathrm{kGy} / \mathrm{h}$ Therefore, JC $2 \gamma-300$ should be evaluated to identify whether it is better than natural J. curcas (JC). One evaluation of JC2 $\gamma-300$ is to assess the quality of the biodiesel derived from its oil (JCO2 $\gamma-300)$.

Alternative fuels such as biodiesel are an energy source produced through the simple process of trans-esterification [3], where vegetable oils commonly known as triacylglycerols (TAG) react with an alcohol to produce fatty acid methyl esters (FAME), known as biodiesel $[1,3,4]$. Generally, the free fatty acid of jatropha oil is high (FFA $>1 \%$ ); thus, a pre-esterification process is necessary to reduce the FFA to less than $1 \%$ so that the process of trans-esterification can run well $[3,5]$. A successful trans-esterification process can be evaluated from a number of factors, such as the percentage of esters being greater than $96.5 \%$ and FFA and water content less than $0.25 \%$ and $0.05 \%$, respectively. This process can be evaluated using HPLC [6] and NMR [2].

The physicochemical properties of biodiesel are the quality of the biodiesel itself. Biodiesel as a fuel should consider various factors including purity (ester content), cetane number, humidity, FFA content

\footnotetext{
* Corresponding author. Tel.: +603-89213915; fax: +603-89215410.

E-mail addresses: ibdalsatar@yahoo.com, ibdalsatar@gmail.com (I. Satar), jumat@ukm.edu.my (J. Salimon).
}

and the ultimate elements of the NCHS-O. American Standard ASTM D6751 and European standard EN 14214 have set values for each parameter, where biodiesel for vehicle fuel must meet these standards. In this research, as a comparison, we evaluate the physicochemical properties of biodiesel derived from JCO and JCO2 $\gamma-300$ feedstocks.

\section{Materials and methods}

All materials such as petroleum ether, potassium hydroxide, sulfuric acid, chloroform, acetone, acetonitrile, methanol and ammonium hydroxide were provided by Fischer Chemical suppliers. The J. curcas without gamma irradiation (JC) and the second generation of gammairradiated J. curcas seeds (JC2 $\gamma-300)$ were collected from Kompleks Rumah Tumbuhan Universiti Kebangsaan Malaysia, Bangi.

\subsection{Irradiation treatments}

Irradiation treatments on the JC seed were performed using cobalt60 as a gamma source $\left({ }^{60} \mathrm{Co}-\right.$ Gammacell 220 Excell equipment) with a dose of $300 \mathrm{kGy} / \mathrm{h}$, and the product was labeled as first-generation gamma-irradiated J. curcas (JC $\gamma-300$ ). Then, the JC $\gamma-300$ was planted in open area until fruiting. After that, the fruit was replanted to produce the second generation gamma irradiated J. curcas (JC2 $\gamma-300)$.

\subsection{Extraction and characterization of oil}

Approximately $500 \mathrm{~g}$ of the fine-grained sample was extracted by the Soxhlet method using petroleum ether as a solvent with a ratio of $6: 1(\mathrm{v} / \mathrm{w})$ for $12 \mathrm{~h}$ [7]. The extraction yield was separated using a rotating evaporator (BUCHI Rotavapor R-124) at a temperature 
of $60-65{ }^{\circ} \mathrm{C}$. Then, the oil was weighed and stored in a refrigerator for further analysis. The physicochemical properties such as the FFA, iodine value, saponification value, unsaponification value, humidity, energy content, cetane number, PE and elemental ultimate analysis NCHSO were determined as described by Jumat [8], Waled and Jumat [9], Azam et al. [10] and NCHS methods, respectively.

\subsection{Production and characterization of biodiesel}

The JCO biodiesel (JCB) and the JCO2 $\gamma-300$ biodiesel (B2 $\gamma-300)$ were produced through two-step processes (pre-esterification by using an acid catalyst and trans-esterification by using a base catalyst) due to their high FFA levels. Then, the yield was separated by using separator funnel. The top layer is the biodiesel, subsequently washed with warm water until $\mathrm{pH}=7.0$. The water content of the biodiesel was removed by using rotary evaporator at a temperature of $60-65^{\circ} \mathrm{C}$. The B $2 \gamma-300$ percentage was determined by using HPLC and NMR methods as described by Shang et al. [6]. The methyl ester percentage (C) was determined by Eq. (1).

$C(\%)=\left(\frac{2 \times A_{\mathrm{ME}}}{3 \times A_{\mathrm{CH}_{2}}}\right) \times 100 \%$

where $C$ is the percentage of triacylglycerol conversion into ester, $A_{\mathrm{ME}}$ is the integration of the methyl ester protons (singlet) and $A_{\mathrm{CH}_{2}}$ is the integration of methylene proton. Factors 2 and 3 are based on the fact that methylene has two protons and methanol has three protons $[2,11]$.

The cetane number (CN), saponification value (SV) and iodine value (IV) was determined by using Eqs. (2), (3) and (4), respectively, as follows:

$\mathrm{CN}=46.3+(5458 / \mathrm{SV})-(0.225 \times \mathrm{IV})$

$\mathrm{SV}=\Sigma\left(560 \times A_{i}\right) / M W_{i}$

$\mathrm{IV}=\Sigma\left(254 \times D \times A_{i}\right) / M W_{i}$

where $\mathrm{CN}, \mathrm{SV}, \mathrm{IV}, A_{i}, D$ and $\mathrm{MW}_{i}$ are the cetane number, saponification value, iodine value, percentage of each component of fatty acid methyl ester, number of double bonds and molecular weight of each component of fatty acid methyl ester, respectively [10].

\subsection{Analysis of phorbol ester composition in oil, seeds residue and biodiesel}

The PE composition in the JCO and JCO2 $\gamma$-300 was determined by using the HPLC method as described by Waled and Jumat [9]. A total of $0.25 \mathrm{~mL}$ of sample was dissolved in $2 \mathrm{~mL}$ of a mixture of acetone and acetonitrile with a ratio of 63.5:36.5 and shaken. The mixture was filtered with a membrane filter with porous size of $0.45 \mu \mathrm{m}$ and then analyzed by using HPLC-ELSD. The PE composition is the area of the peaks that appeared at the retention time of 6-11 min.

The PE composition in the seed residue was determined by using the HPLC method as described by Haas and Mittelbach [12]. A total of $10.0 \mathrm{~g}$ of the seed residue was inserted into the conical flask followed by the addition of $30 \mathrm{~mL}$ of methanol $30 \mathrm{~mL}$ and shaken for 5 min then filtered with Whatman No. 1 filter paper. This process was repeated as many as five times. The extraction yield was dried by rotary evaporator and then dissolved in $5 \mathrm{~mL}$ of methanol and filtered with a membrane filter with a pore size of $0.45 \mu \mathrm{m}$. Injecting approximately $20.0 \mu \mathrm{L}$ of the solution, the mobile phase was a mixture of acetonitrile and water with ratio 80:20, flow rate $1 \mathrm{~mL} / \mathrm{min}$, retention time $30 \mathrm{~min}$ and the detector wavelength was $280 \mathrm{~nm}$. The PE peaks appeared at a retention time of 6-11 min. The PE composition in the JCB and B2 $\gamma-300$ were determined by using the HPLC method as described by Waled and Jumat [9].
Table 1

Physicochemical properties of JCO and JCO2 $\gamma-300$.

\begin{tabular}{|c|c|c|}
\hline Parameter & $\mathrm{JCO}$ & $\mathrm{JCO} 2 \gamma-300$ \\
\hline Oil content (\%) & 46 & 51.7 \\
\hline FFA value $(\%)$ & 3.5 & 1.4 \\
\hline Iodine value $\left(\mathrm{mg} \mathrm{I}_{2} / \mathrm{g}\right)$ & 95.7 & 94.2 \\
\hline Saponification value $(\mathrm{mg} \mathrm{KOH} / \mathrm{g})$ & 213.7 & 206.0 \\
\hline Unsaponification matter (\%) & 0.6 & 0.8 \\
\hline Viscosity (cSt) at $40^{\circ} \mathrm{C}$ & 23.9 & 23.5 \\
\hline Density $(\mathrm{g} / \mathrm{mL})$ & 0.90 & 0.89 \\
\hline Energy content $(\mathrm{kJ} / \mathrm{g})$ & 40.5 & 38.1 \\
\hline PE composition $(\%)$ & $1.39\left(2.45^{\mathrm{a}}\right)$ & nd $\left(0.14^{\mathrm{b}}\right)$ \\
\hline \multicolumn{3}{|l|}{ Ultimate element composition (\%) } \\
\hline $\mathrm{N}$ & 0.29 & 0.34 \\
\hline $\mathrm{C}$ & 73.08 & 71.15 \\
\hline $\mathrm{H}$ & 9.68 & 10.31 \\
\hline $\mathrm{S}$ & 0.00 & 0.00 \\
\hline 0 & 16.95 & 18.20 \\
\hline
\end{tabular}

\subsection{Ultimate elemental analysis of NCHSO and purity of biodiesel}

Analysis of the ultimate elements of $\mathrm{N}, \mathrm{C}, \mathrm{H}, \mathrm{S}$, and $\mathrm{O}$ are determined by the NCHS method. The percentage of oxygen can be determined by Eq. (5), as follows:

Percentage of oxygen $(\% \mathrm{O})=100-(\% N+\% C+\% H+\% S)$

where $\% \mathrm{O}$ is the percentage of oxygen, $\% \mathrm{~N}$ is the percentage of nitrogen, \% $\mathrm{C}$ is the percentage of carbon, \% $\mathrm{H}$ is the percentage of hydrogen and \% S is the percentage of sulfur. Factor 100 is the total composition of the ultimate elements in the sample.

The HPLC and ${ }^{1} \mathrm{H}$ NMR methods were used for the analysis of biodiesel. Analysis of biodiesel purity by the HPLC method performed such an analysis on Jatropha oil, whereas the ${ }^{1} \mathrm{H}$ NMR method by using the DELTA NMR ECP 400 equipment. A total of $20 \mathrm{mg}$ of sample was dissolved in $0.65 \mathrm{~mL}$ of $\mathrm{CDCl}_{3}$, shaken for a few second and inserted into the NMR tube, then analyzed by NMR.

\section{Results and discussion}

\subsection{Oil content and characterization}

The oil content of JC and JC2 $\gamma$-300 seeds were $46 \%$ (denoted as JCO) and 52\% (denoted as JCO2 $\gamma-300$ ), respectively. The water content and FFA values were $0.2 \%$ and $3.4 \%$ for JC and $0.2 \%$ and $1.4 \%$ for JC2 $\gamma-300$, respectively. According to the findings of Canakci and Gerpen [13], Demirbas [1] and Romano [14] that the trans-esterification process using base catalyst, water content and FFA leads to the formation of soaps, the separation of the methyl esters and glycerol would be complicated, reducing the biodiesel yield. In fact, Kusdiana and Saka [15] argued that the effect of high humidity was worse than the effects of the FFA because water can accelerate microbial propagation in the oil, which causes the oil to be easily damaged. Table 1 shows some of the physicochemical properties of JCO and JCO2 $\gamma$-300 such as the iodine value, saponification value, unsaponification value, energy content and cetane number. In general, the physicochemical properties of $\mathrm{JCO} 2 \gamma-300$ and JCO are very close. However, the PE composition in the JCO $2 \gamma-300$ was lower (not detected) than JCO. This indicates that the high dose of gamma irradiation caused the degradation of PE into other compounds such as fatty acids. This fact also indicates that JCO $2 \gamma-300$ is less toxic than JCO. It was also observed that the iodine value of JCO was decreased by gamma irradiation. The result confirms that the gamma irradiation accelerates the auto-oxidation process of unsaturated fatty acids in the presence of oxygen through the formation of free radicals, causes 

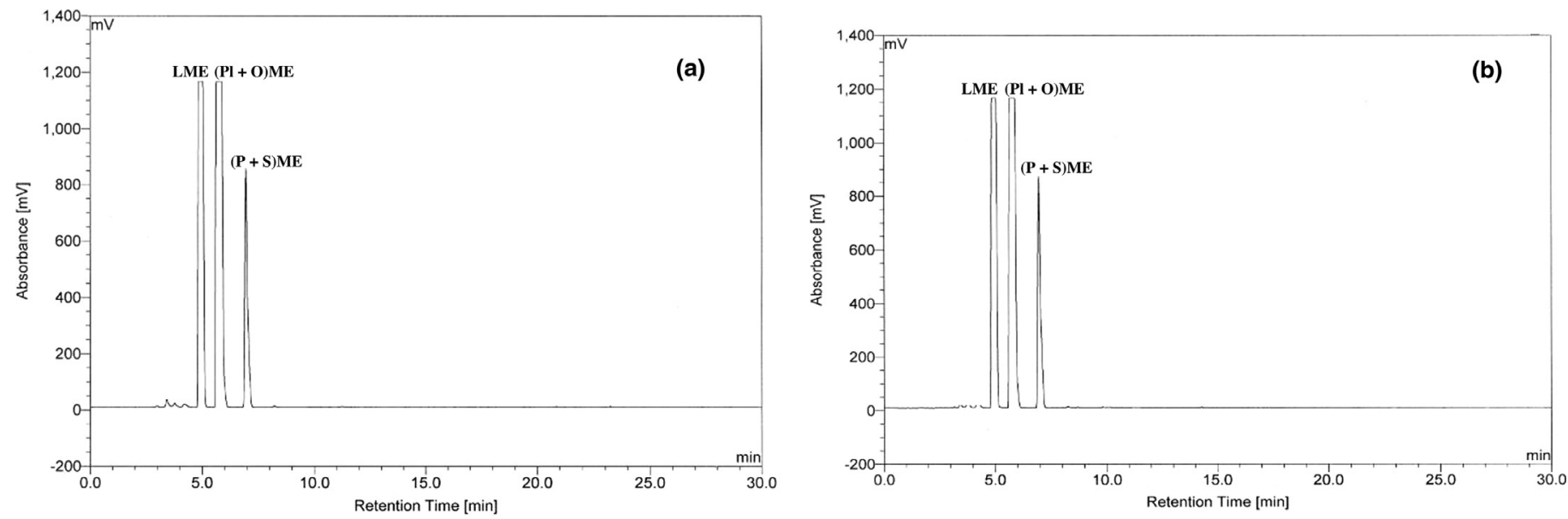

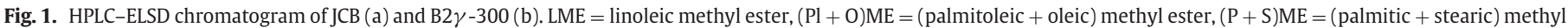
ester.

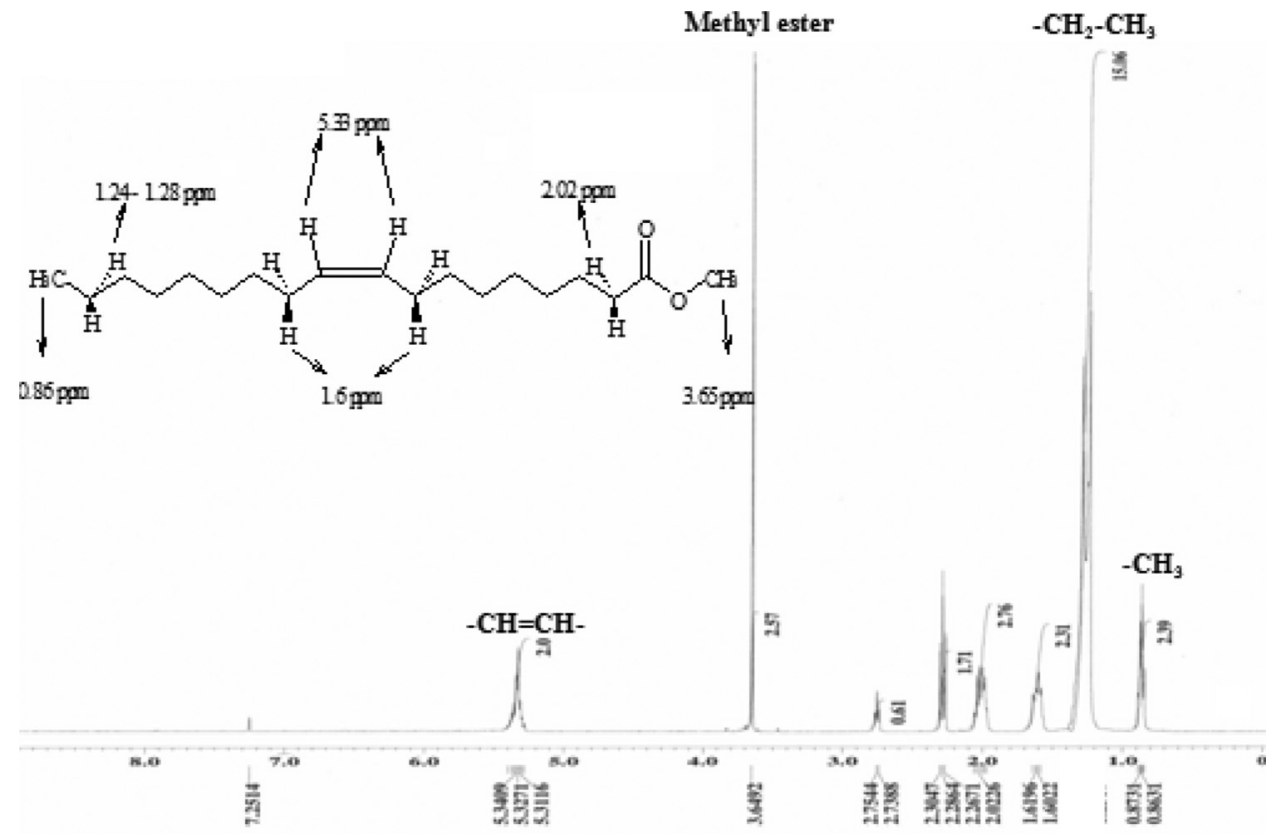

Fig. 2. ${ }^{1} \mathrm{H}$ NMR spectrum of $\mathrm{B} 2 \gamma-300$

Table 2

Methyl ester composition of JCB and B2 $\gamma-300$ based on HPLC-ELSD.

\begin{tabular}{llllll}
\hline Type of fatty acid methyl ester & \multicolumn{2}{l}{ Retention time (min) } & & $\%$ Area \\
\cline { 5 - 6 } & JCB & B2 $\gamma-300$ & & JCB & B2 $\gamma-300$ \\
\hline Linoleic methyl ester (LME) & 4.85 & 4.85 & & 37.52 & 37.58 \\
Palmitoleic + oleic methyl ester (Pl + O)ME & 5.63 & 5.64 & & 47.18 & 47.12 \\
Palmitic + stearic methyl ester (P + S)ME & 6.95 & 6.94 & & 14.60 & 14.40 \\
Total & & & & 99.20 & 99.10 \\
\hline
\end{tabular}

the breakdown and destruction of the anti-oxidants, and changes the chemical constituents of the lipid fraction [16].

In addition to the oil, J. curcas seed contains approximately $18 \%$ protein $[17,18]$. Therefore, the extraction of JC and JC2 $\gamma-300$ seeds using petroleum ether would obtain oils containing approximately $0.29 \%$ and $0.34 \%$ nitrogen, respectively. Based on the elemental analysis (NCHSO), Wever [19] reported that the extraction of jatropha shell by using a non-polar (ethanol/cyclohexane) solvent obtained a nitrogen $(\mathrm{N})$ composition $(0.01 \%)$ lower than by using the polar solvent (water), approximately $0.6 \%$. This explains why biodiesel contains nitrogen.

\subsection{Production and characterization of $B 2 \gamma-300$}

The pre-esterification process using sulfuric acid as catalyst can reduce the FFA value to less than $1 \%$. This indicates that the oil was suitable for the trans-esterification process by using base catalyst. The separation of methyl esters and glycerol was easy due to the lack of 
Table 3

\begin{tabular}{lcclll}
\multicolumn{7}{l}{ Physicochemical properties of B2 $\gamma-300$, JCB and JME. } \\
\hline Parameter & B2 $\gamma-300$ & JCB & JME & ASTM D6751 & EN $14214^{\mathrm{b}}$ \\
\hline Acid value $(\mathrm{mg} \mathrm{KOH} / \mathrm{g})$ & 0.26 & 0.32 & 0.27 & $\geq 0.8$ & $\geq 0.5$ \\
\% FFA & 0.13 & 0.16 & - & - & - \\
Water content $(\%)$ & 0.013 & 0.015 & $0.07-0.1$ & $<0.03$ & $<0.05$ \\
Iodine value $(\mathrm{mg} / \mathrm{g})$ & 111.5 & 114.5 & $93-106$ & - & 120 \\
Density $\left(24{ }^{\circ} \mathrm{C}, \mathrm{g} / \mathrm{mL}\right)$ & 0.87 & 0.88 & 0.88 & - & $0.86-0.90$ \\
Viscosity $(\mathrm{cSt})$ & 4.9 & 4.9 & 5.1 & $1.9-6$ & $3.5-5.0$ \\
Energy content $(\mathrm{kJ} / \mathrm{g})$ & 38.9 & 39.3 & 39.6 & - & - \\
Cetane number & 52.2 & 52.3 & 52.3 & $\leq 51$ & $\leq 47$ \\
Cloud point $\left({ }^{\circ} \mathrm{C}\right)$ & 8 & 8 & - & - & - \\
Flash point $\left({ }^{\circ} \mathrm{C}\right)$ & 157 & 158 & 186 & $<130$ & - \\
Ash $(\%)$ & 0.01 & 0.002 & - & 0.01 & - \\
Methyl ester $(\%)$ & 99.1 & 99.2 & 99.6 & - & - \\
PE composition $(\%)$ & nd & nd & - & - & -
\end{tabular}

Note: JME = Jatropha methyl ester; (Sources a: Achten et al. [20]). ASTM D6751 and EN 14214 standards (Sources of $b$ : Demirbas [1]).

emulsion. The HPLC chromatograms of JCB and B2 $\gamma-300$ (Fig. $1 \mathrm{a}$ and b) show three major peaks. According to Shang et al. [6] the separation of fatty acid methyl ester peaks are based on the molecular weight and the number of double bonds. The retention time increases with the decrease of the molecular weight and the number of double bonds. Therefore, three peaks are expected as linoleic methyl ester (LME), palmitoleic + oleic acid methyl ester $(\mathrm{Pl}+\mathrm{O}) \mathrm{ME}$ and palmitic + stearic methyl ester $(\mathrm{P}+\mathrm{S}) \mathrm{ME}$ that appear at retention times of 4-7 min. The ester percentages of JCB and B2 $\gamma-300$ were $99.2 \%$ and $99.1 \%$, respectively (Table 2 ), as calculated based on the areas of the three peaks. Meanwhile, the LME, $(\mathrm{Pl}+\mathrm{O}) \mathrm{ME}$ and $(\mathrm{P}+\mathrm{S}) \mathrm{ME}$ composition in JCB and $\mathrm{B} 2 \gamma-300$ were in the ranges of $37.0 \%, 47.0 \%$ and $14.0 \%$, respectively.

In this paper, the ${ }^{1} \mathrm{H}$ NMR spectrum of JCB was not shown because the biodiesel ${ }^{1} \mathrm{H}$ NMR spectra were similar. The ${ }^{1} \mathrm{H}$ NMR spectrum shows that the triacylglycerol composition was converted to fatty acid methyl esters (Fig. 2). The peaks of methylene protons $\left(-\mathrm{CH}_{2}-\mathrm{CH}_{2}-\mathrm{O}-\right)$ and methoxy $\left(-\mathrm{O}-\mathrm{CH}_{3}\right)$ of the methyl ester are shown at $2.3 \mathrm{ppm}$ and $3.6 \mathrm{ppm}$, respectively. The integration value of each peak was obtained, and it was shown that the triacylglycerol was fully converted into the methyl ester. Table 3 shows that the physicochemical properties of B2 $\gamma-300$, JCB and JME [20] compare to the ASTM D6751 and EN 14214 standards [1]. However, as a whole, the physicochemical properties of B2 $\gamma-300$, JCB and JME satisfied the ASTM D6751 and EN 14214 standards. The B2 $\gamma-300$ showed a lower acid value, water content and flash point of $0.26 \mathrm{mg} \mathrm{KOH} / \mathrm{g}, 0.0013 \%$ and $157{ }^{\circ} \mathrm{C}$, respectively, which can affect the flammability properties at a lower temperature compared to the JME from the reference. These facts imply that the JCO $2 \gamma-300$ has good properties as a new source for biodiesel production.

\subsection{Phorbol ester composition}

Figs. 1(a and b), 3 and 4 show the HPLC-ELSD chromatograms of JCB, B $2 \gamma-300, \mathrm{JCO} 2 \gamma-300$ and PE in the seed residue, respectively. This research found that the PE composition was not detected in the JCO $2 \gamma-300$ and B $2 \gamma-300$ compared to $1.39 \%$ in JCO, while the PE compositions in the seed residue of JCO and JCO2 $\gamma$-300 were $2.45 \%$ and $0.14 \%$, respectively (Table 1 and 3 ). There was shown a significant difference in PE content between JC and JC2 $\gamma$-300. It was indicated that the gamma irradiation can genetically change the J. curcas seed. PE is thermally unstable and susceptible to oxidation, trans-esterification and epimerization; therefore, JCB and $\mathrm{B} 2 \gamma-300$ have no PE. However, the PE composition in the JC2 $\gamma$-300 seed residue was lower than that in the JCO and its seed residue. This result implies that the PE was influenced by genetic factors and was affected by soil and climate [21].
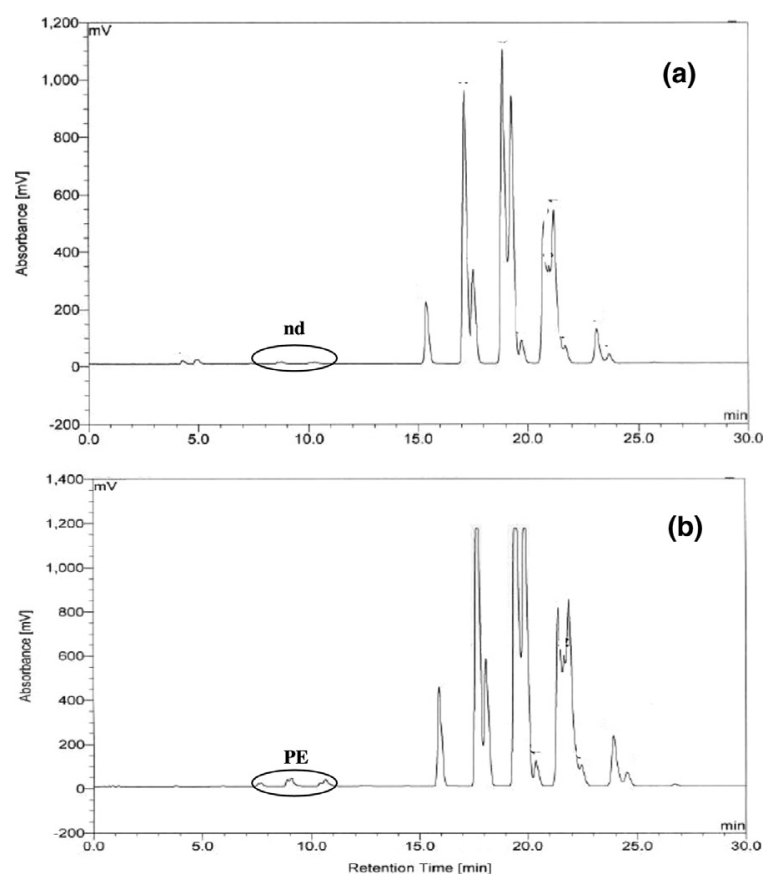

Fig. 3. HPLC-ELSD chromatogram of phorbol ester in JCO2 $\gamma-300$ (a) and JCO (b). PE $=$ phorbol ester; nd = not detected.

\subsection{Elemental composition}

Table 4 shows that both the JCB and B2 $\gamma-300$ have no sulfur. Thus, it can be expected that the JCB and $\mathrm{B} 2 \gamma-300$ would produce no $\mathrm{SO}_{x}$ emissions [22]. However, the nitrogen contents of JCB and $\mathrm{B} 2 \gamma$ 300 were $0.18 \%$ and $0.24 \%$ higher than that of petro-diesel , $0.02 \%$. Therefore, the predicted $\mathrm{NO}_{x}$ emissions of JCB and $\mathrm{B} 2 \gamma-300$ would be higher than that of petro-diesel.

The main factor that distinguishes biodiesel from petro-diesel was oxygen, as the petro-diesel contains no oxygen [23]. The presence of oxygen in biodiesel and the supply of oxygen from the atmosphere may cause the biodiesel combustion process to be more complete than that of petro-diesel. This research demonstrated that the oxygen contents of JCB and B2 $\gamma-300$ were lower than that of biodiesel produced from waste cooking oil (WCO) as reported by Kumaran [22]. The hydrogen and carbon contents of JCB and B2 $\gamma-300$ were lower than those of petro-diesel, but higher than WCO. It can be predicted that during the performance and fuel emission testing, the emission of $\mathrm{CO}, \mathrm{CO}_{2}$ and $\mathrm{NO}_{x}$ from JCB and $\mathrm{B} 2 \gamma-300$ would be lower than that of petro-diesel. 

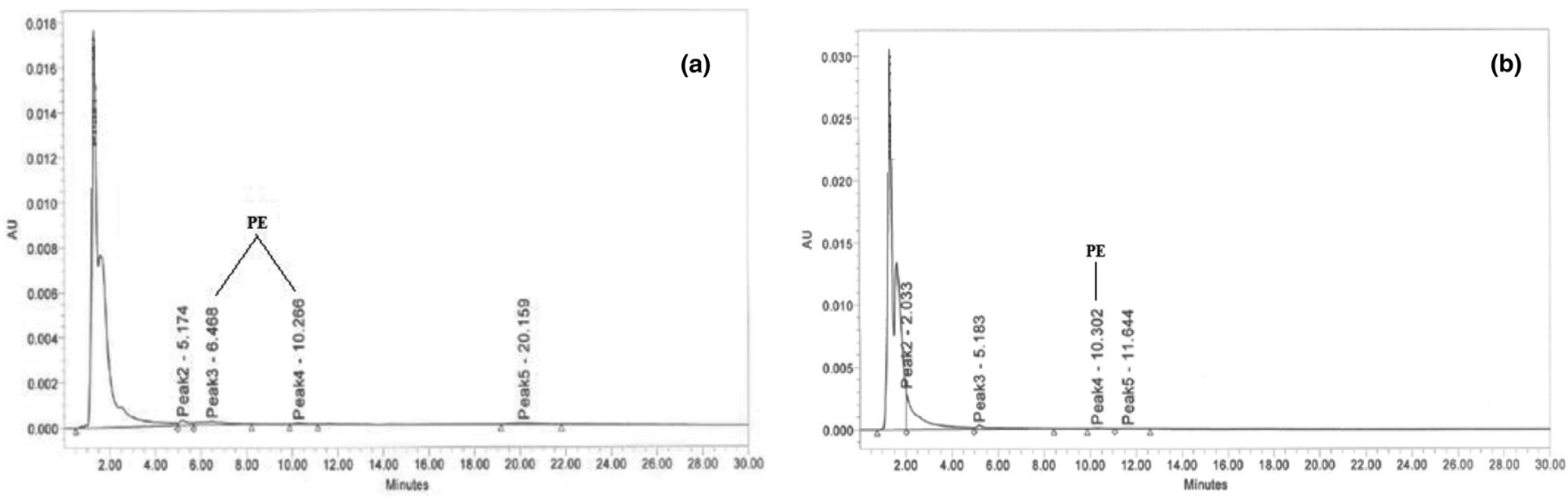

Fig. 4. HPLC-UV chromatograms of PE in seed residue of JC (a) and JC2 $\gamma-300$ (b).

Table 4

NCHSO composition of JCB, B2 $\gamma-300$, WCO and petro-diesel (Sources of $a$ and $b$ : Kumaran et al. [22]).

\begin{tabular}{llllll}
\hline \multirow{2}{*}{ Sample } & \multicolumn{5}{l}{ Element composition (\%) } \\
\cline { 2 - 6 } & Nitrogen & Carbon & Hydrogen & Sulfur & Oxygen \\
\hline JCB & 0.18 & 79.20 & 12.35 & 0.00 & 8.27 \\
$\mathrm{~B} 2 \gamma-300$ & 0.24 & 80.54 & 12.57 & 0.00 & 6.65 \\
WCO $^{\mathrm{a}}$ & 0.00 & 72.30 & 11.70 & 0.01 & 15.99 \\
Petro-diesel & 0.02 & 86.48 & 13.00 & 0.50 & - \\
\hline
\end{tabular}

The HPLC and ${ }^{1} \mathrm{H}$ NMR analysis found that the ester composition was high, more than 99.0\%. The ester composition of biodiesel according to ASTM D6751 and EN 14214 was more than 96\%. This indicates that the purity of JCB and $\mathrm{B} 2 \gamma-300$ is good. The HPLC chromatogram shows that the impurities of JCB and B $2 \gamma-300$ were approximately $0.9 \%$. These impurities most likely were due to the presence of free fatty acids, unreacted methanol, glycerol and other organic mixtures.

\section{Conclusions}

The gamma radiation exposure results in higher oil and lower PE content for JC $2 \gamma-300$ compared to JC. This indicates that oil and PE composition are influenced by gamma radiation, which genetically changes the JC, in addition to the effects of climate and soil condition. In terms of oil content, JC $2 \gamma-300$ is a new raw material source for biodiesel production with better quality than JC. The low FFA value $(<0.5 \%)$ can produce biodiesel with a high ester content $(>99 \%)$. The HPLC and ${ }^{1} \mathrm{H}$ NMR methods can be used for biodiesel purity analysis. The physicochemical properties such as lower iodine value and water content and higher cetane number of B2 $\gamma$-300 meet the ASTM D6751 and EN 14214 standards.

\section{Acknowledgment}

The authors would like to thank Universiti Kebangsaan Malaysia for the financial grant DPP-2013-045 during this study.

\section{References}

[1] Demirbas A. Progress and recent trends in biodiesel fuels. Energy Convers Manage 2009;50:14-34.
[2] Prasad L, Pradhan S, Das LM, Naik SN. Experimental assessment of toxic phorbol ester in oil, biodiesel and seed cake of Jatropha curcas and use of biodiesel in diesel engine. Appl Energy 2012;93:245-50.

[3] Gerpen VJH. Biodiesel processing and production. Fuel Process Technol 2005; $86: 1097-107$.

[4] Xu R, Wang R, Liu A. Expression profiles of genes involved in fatty acid and triacylglycerol synthesis in developing seeds of Jatropha (Jatropha curcas L.). Biomass Bioenergy 2011;35:1683-92.

[5] Tiwari AK, Kumar A, Raheman H. Biodiesel production from Jatropha oil (Jatropha curcas) with high free fatty acids: an optimized process. Biomass Bioenergy 2007;31:569-75

[6] Shang NC, Liu RZ, Chen YH, Chang CY, Li RH. Characterization of fatty acid methyl esters in biodiesel using high-performance liquid chromatography. J Taiwan Inst Chem Eng 2012;43:354-9.

[7] Sepidar S, Abidin ZZ, Yunus R, Muhammad A. Extraction of oil from jatropha seeds-optimization and kinetics. AJAS 2009;6:1390-5.

[8] Jumat S, Pertama C, editors. Oils and fats analysis. Selangor Darul Ehsan: Fakulti Sains dan Teknologi, Universiti Kebangsaan Malaysia 43600 UKM Bangi; 2006.

[9] Waled AA, Jumat S. Phorbol ester as toxic constituents of tropical Jatropha curcas seed oil. Eur J Sci Res 2009;31:429-36.

[10] Azam MM, Waris A, Nahar NM. Prospects and potential of fatty acid methyl esters of some non-traditional seed oils for use as biodiesel in India. Biomass Bioenergy 2005;29:293-302.

[11] Gelbard G, Bres O, Vargas RM, Vilefaure F, Schuchard UF. ${ }^{1} \mathrm{H}$ nuclear magnetic resonance determination of the yield of the transesterification of rapeseed oil with methanol. J Am Oil Chem Soc 1995;2:1239-41.

[12] Haas W, Mittelbach M. Detoxification experiments with the seed oil from Jatropha curcas L. Ind Crop Prod 2000;12:111-18.

[13] Canakci M, Gerpen JV. Biodiesel production by acid catalysis. Trans Am Soc Agric Eng 1999;42:1203-10.

[14] Romano S. Vegetable oils-a new alternative. In: Vegetable oils fuels-proceedings of the international conference on plant and vegetable oils as fuel. Fargo, ND, USA: ASAE Publication; 1982. p. 101-16.

[15] Kusdiana D, Saka S. Kinetics of transesterification rapeseed oil to biodiesel fuel as tested in supercritical methanol. Fuel 2001;80:693-5.

[16] Hafez YS, Mohamed AI, Singh G, Hewedy FM. Effect of gamma irradiation on protein and fatty acids of soybean. J Food Sci 1985;50:1271-4.

[17] Montes JM, Aliciardi MR, Chavez JV, Guzman C, Calandrti E. Characterization of Jatropha curcas L. seed and its oil, from Argentina and Paraguay. J Arg Chem Soc 2011;98:1-9.

[18] Malviya SN, Malakar R, Yadav M, Mishra A, Tiwari A. Estimation and characterization of protein present in seed extract of Jatropha curcas. ARPB 2011;1:35-44.

[19] Wever DAZ, Heeres HJ, Broekhuis AA. Characterization of physic nut (Jatropha curcas L.) shells. Biomass Bioenergy 2012;37:177-87.

[20] Achten WMJ, Verchot L, Franken YJ, Mathijs E, Singh VP, Aert R, et al. Jatropha bio-diesel production and use. Biomass Bioenergy 2008;32:1063-84.

[21] Makkar HPS, Aderibidge AO, Becker K. Comparative evaluation of non-toxic and toxic varieties of Jatropha curcas for chemical composition, digestibility, protein degradability and toxic factors. Food Chem 1997;62:207-15.

[22] Kumaran P, Mazlini N, Hussein I, Nazrain M, Khairul M. Technical feasibility studies for Langkawi WCO (waste cooking oil) derived-biodiesel. Energy 2011;33:1-8.

[23] Nazrain M. An evaluation of Malaysian waste cooking oil based biodiesel properties and performance. In: Proceeding of shell inter-varsity paper presentation contest (SSPEC) 2005 